\title{
La gnomonica antica tra arte e scienza: geometria, storia e astronomia per il restauro dell'orologio solare della Certosa di San Martino
}

\author{
Alessandra Pagliano
}

\section{Abstract}

Nel mondo greco esistono tre interessanti modalità rappresentative del concetto di Tempo, ciascuna associata a una specifica forma iconografica. Un orologio solare, come rappresentazione del tempo e dello spazio nel quale avviene il moto apparente del Sole, presenta un insieme di curve, rette, simboli e iscrizioni associabili alla mitologia delle tre figure greche del Tempo. A dispetto del valore scientifico e artistico, numerosi orologi solari non sono adeguatamente conservati e valorizzati per il progressivo disperdersi di questa antica cultura millenaria.

Il presente contributo illustra il metodo geometrico adottato per restituire al Chiostro grande della Certosa di San Martino a Napoli il suo antico orologio solare, per il quale è stato necessario disegnare un nuovo reticolo del tempo che potesse funzionare correttamente in relazione allo gnomone esistente; sulla base delle informazioni fornite da un dipinto di G. Carelli si è scelto di ripristinare l'antico sistema orario all'italiana, sebbene oggi in disuso.

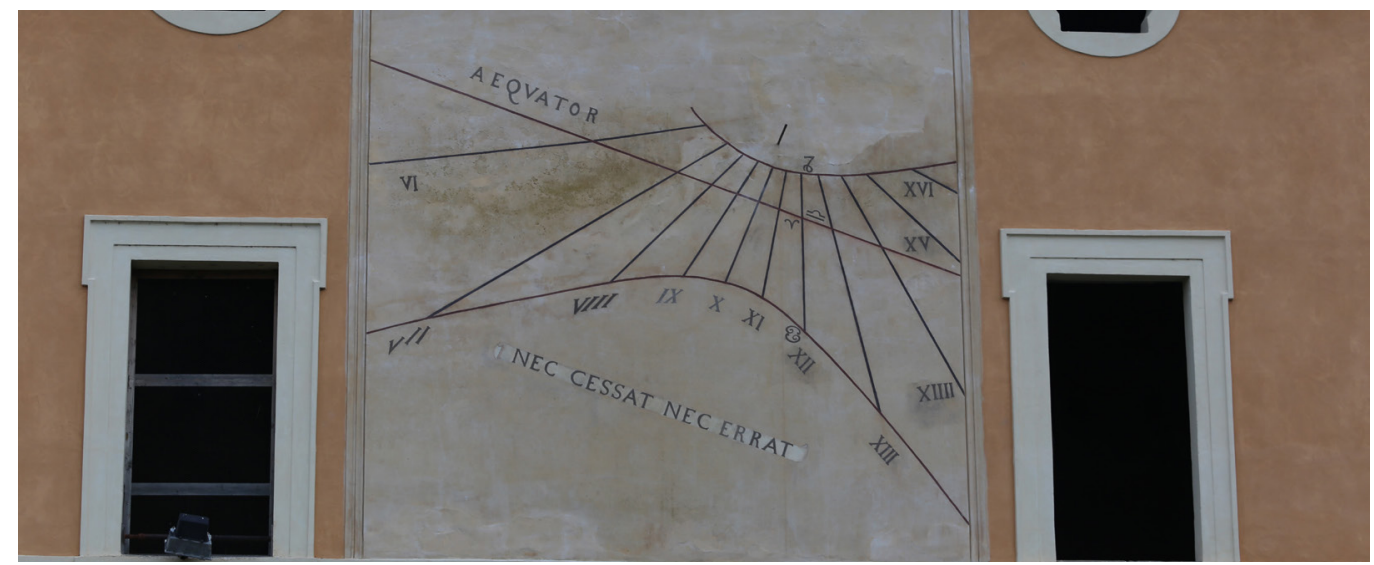




\section{II quadrante solare come rappresentazione del tempo attraverso il mito di Cronos, Aion e Kairos}

La misura del tempo è stata per millenni uno degli organizzatori cognitivi fondamentali, insieme al concetto di spazio, per la descrizione e l'interpretazione dei fenomeni naturali. Nei popoli primitivi era un'esigenza direttamente legata alla sopravivenza: l'uomo avvertiva la necessità di individuare il mezzogiorno, immaginaria linea di confine fra mattino e pomeriggio che consentiva di programmare le attività, evitando il rischio di essere sorpresi dalle tenebre, lontani dal rifugio.

Quando l'uomo divenne agricoltore, nacque il bisogno di conoscere e misurare la durata degli eventi climatici che inducevano trasformazioni significative nel proprio territorio, dovute principalmente all'alternanza delle stagioni di cui bisognava poter prevedere il ciclico ritorno, al fine di programmare le azioni di preparazione del suolo per la semina o il raccolto. Le prime interpretazioni dei fenomeni astronomici visibili ad occhio nudo furono basate sull'evidenza che gli astri e i pianeti compissero moti regolari dall'andamento ciclico. L'indiscutibilità di tali osservazioni, alle diverse latitudini terrestri, portò alla formulazione dell'idea filosofica-religiosa che riteneva l'uomo al centro dell'Universo. I più importanti modelli cosmologici antichi furono dunque geocentrici, fortemente intrisi di elementi mitologici.

Nell'antica Grecia, il concetto di tempo era oggetto di riflessioni filosofiche per la sua duplice natura di dimensione perpetua (nella sua ininterrotta ciclicità) ma al tempo stesso di fenomeno provvisorio, fuggevole e mutevole. Ogni attimo rappresenta, dunque, un frammento d'eternità.

Nel mondo greco esistono tre interessanti modalità rappresentative del concetto di Tempo, ciascuna associata a una specifica forma iconografica.

Chronos, assimilato progressivamente alla figura mitologica del titano Kronos (Koóvos) e anche a Saturno, è il tempo come successione di istanti, di ore, di giorni, ovvero il tempo che scorre e divora l'esistenza. Una rappresentazione quindi della quantità infinita di attimi successivi. Secondo Galimberti "I'uomo abita quello che Prometeo chiamava 'il tempo che invecchia' e che, invecchiando, mette ancor più a nudo la condizione di mortale [brótos]' a cui gli uomini sono irrimediabilmente consegnati e da cui Prometeo aveva cercato di difenderli ponendo in loro 'cieche speranze"'[Galimberti 2019, p. I48].

La seconda forma associata al concetto greco di tempo è Aion (Aı́́v), il tempo eternamente ciclico e fecondo, legato alla natura, immagine antropomorfa che regge la ruota dei segni dello Zodiaco, simbolo del ciclico avvicendarsi delle stagioni. L'accostamento della figura di Aion con il Sole, con il suo ciclo annuale, ma anche con la Fenice, animale simbolo della rinascita dalla morte, sottolinea l'eterna ciclicità del tempo: "L'accostamento Aion/ Fenice ci introduce in una nuova prospettiva, che non solo sviluppa il simbolismo del Sole in connessione con il tempo sempre identico a sé stesso, ma ne traduce le aspettative di rinnovamento periodico secondo un simbolismo ciclico tra i più diffusi. La Fenice è, infatti, per eccellenza il simbolo della renovatio temporum" [D'Anna I999, p. I48].

Esiste infine Kairos (Kaıpós), il tempo fuggevole dell'attimo, del momento propizio, dell'occasione da cogliere. Rappresenta la costante mutevolezza e, dunque, la 'qualità' del tempo, ovvero la particolarità individuale del singolo istante, sottratto all'astrattezza dello scorrere di attimi tutti uguali. II concetto di tempo cairologico si contrappone a quello cronologico, che ci è più consueto, poiché non considera il tempo nel suo sviluppo lineare e misurabile, ma come momento opportuno, l'istante dell'occasione propizia, il 'tempo giusto' da saper cogliere per compiere la giusta azione.

Un orologio solare, come rappresentazione del tempo e dello spazio nel quale avviene il moto apparente del Sole, presenta un insieme di curve, rette, simboli e iscrizioni associabili alle tre figure greche del Tempo.

II reticolo di linee disegnate su un quadrante piano verticale viene distinto in curve diurne e rette orarie: le prime (di forma iperbolica) corrispondono al percorso dell'estremo dell'ombra proiettata dallo gnomone in un determinato giorno. Ne sono tradizionalmente disegnate tre, corrispondenti a quattro date notevoli del calendario che segnano il passaggio tra le stagioni. L'iperbole più vicina allo gnomone identifica il solstizio invernale mentre 


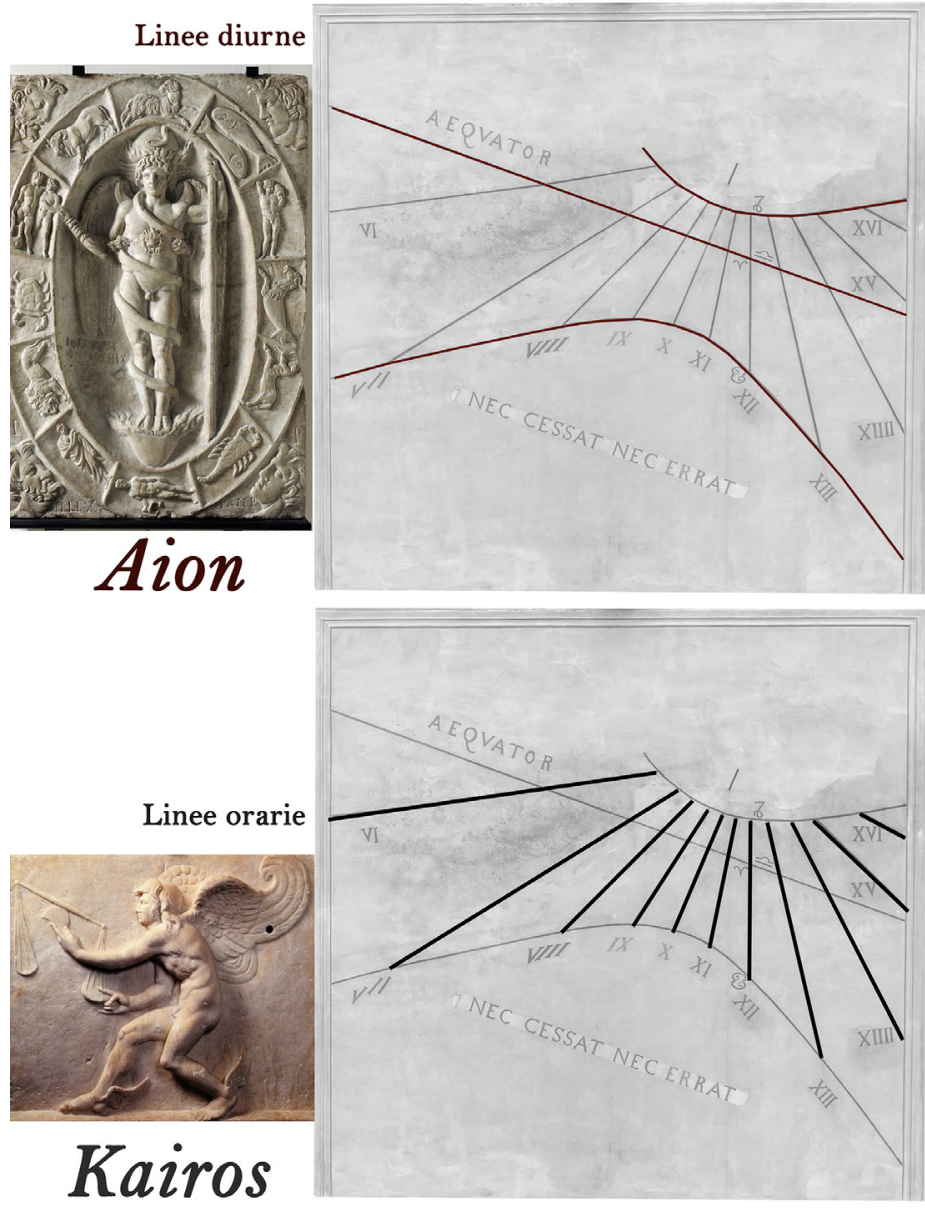

Fig. I. Rappresentazione del tempo tra iconogra
classica e gnomonica.

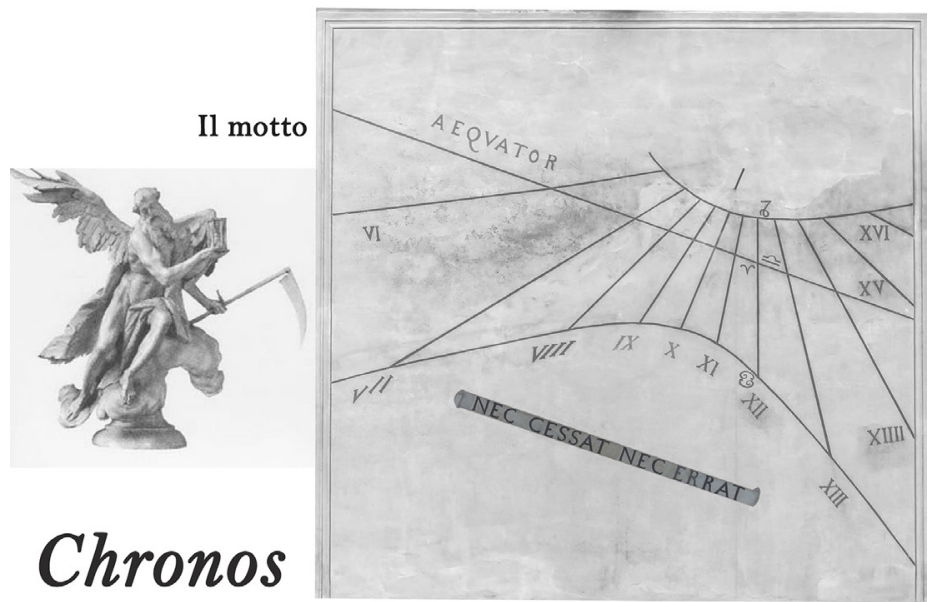


all'opposto limite del reticolo si trova l'iperbole del solstizio estivo. In posizione centrale la retta nella quale coincidono i due giorni del 21 marzo e del 23 settembre, rispettivamente l'equinozio di primavera e quello di autunno. Le curve diurne rappresentano il concetto di tempo ciclico della natura impersonificato da Aion. II tempo cairologico è invece disegnato dalle linee orarie, diverse per ciascun sistema cronometrico, percorse dalla costante mutevolezza diurna dell'ombra dello gnomone, per effetto del moto di rotazione terrestre. Infine, la maggior parte dei quadranti solari, a partire dal XVI secolo, presentano un motto inciso o dipinto, solitamente un memento mori o una considerazione sulla caducità della vita umana: a tale riflessione possiamo associare il concetto di tempo cronologico che sottolinea la mortalità della condizione umana. La figura I mostra uno dei quattro orologi solari restaurati [I] presso il Real sito di Carditello (CE). II soggetto del motto in lingua latina dipinto nel festone è sottinteso, ma si riferisce all'oggetto del quadrante, ovvero il Tempo, rappresentato attraverso la sua proiezione gnomonica nel reticolo delle linee, che nec cessat nec errat [2].

\section{II restauro dell'orologio solare verticale del Chiostro Grande della Certosa di San Martino}

Lungo la facciata principale del Chiostro grande sono collocati due antichi orologi a quadrante circolare. Sul lato destro si trova un orologio meccanico 'a sei ore' [3] e, in posizione simmetrica, si trova un quadrante solare verticale, anch'esso circolare e di uguale diametro. La giacitura della facciata espone la punta dello gnomone ai raggi provenienti dalle direzioni cardinali est, sud-est: tale inclinazione, definita come 'declinazione gnomonica della parete' $(\delta)$, permette all'asta di proiettare la sua ombra dall'alba fino al mezzogiorno, lasciando inattivo l'orologio nelle ore pomeridiane. Per circa un secolo, di questo monumentale orologio rimaneva solo l'originario gnomone infisso nella parete. Si tratta di un'asta metallica dalla punta arrotondata, che sporge di $40 \mathrm{~cm}$ dalla parete in direzione perpendicolare e che dunque assume il termine di 'ortostilo'.

Le foto storiche testimoniano che nel 1910 le linee del quadrante solare fossero già illeggibili: il veloce sbiadimento del tracciato orario dipinto, ma soprattutto l'abbandono delle ore italiche a favore delle ore francesi, hanno certamente determinato il progressivo oblio dell'orologio.

Un dipinto di Gabriele Carelli, dal titolo |l Chiostro grande della certosa di San Martino ( 853 ) raffigura una vista interna in cui compaiono in dettaglio entrambi gli orologi.

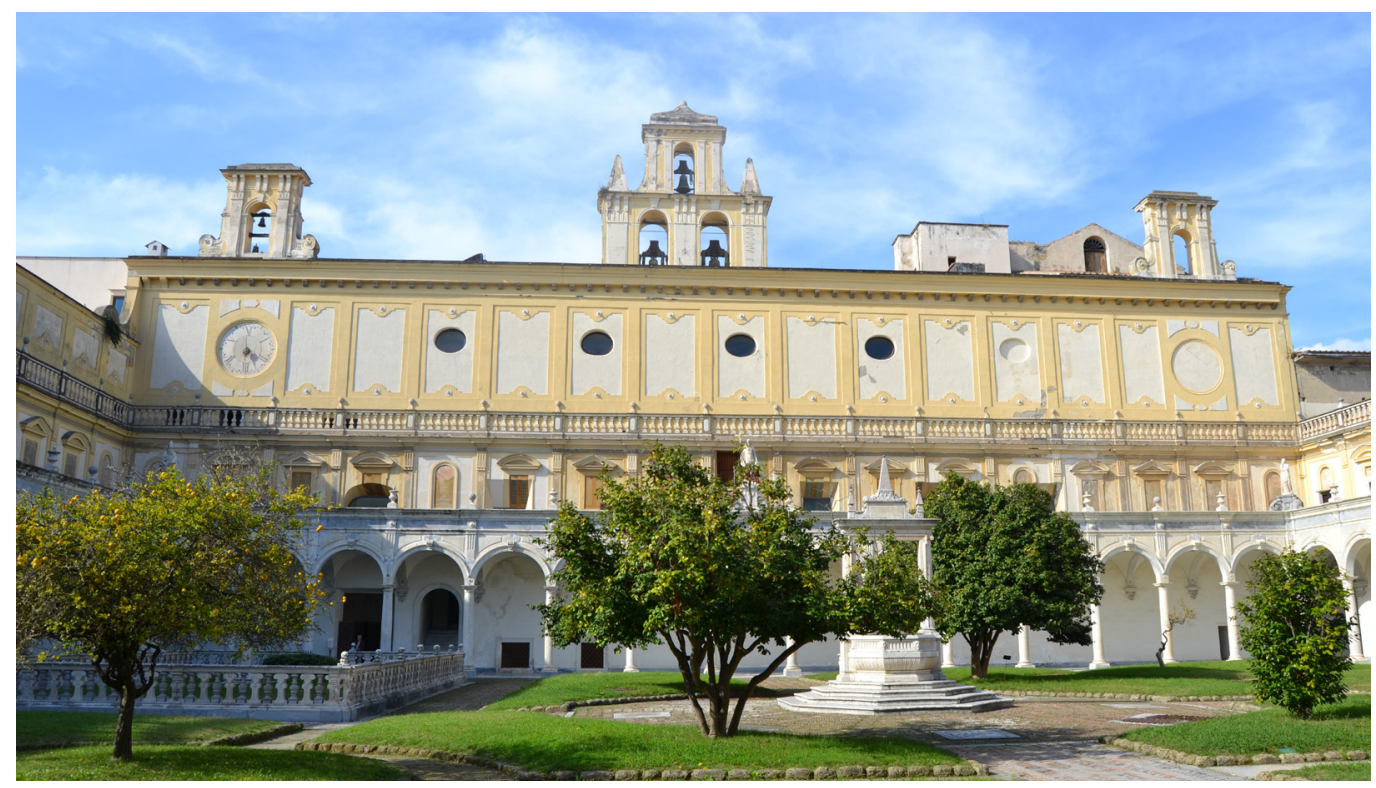


Non è tuttavia possibile affermare con certezza se il sistema orario fosse quello italico o quello ad usum campanae [4], comparso in Italia qualche secolo dopo l'introduzione delle ore italiche, quando i campanili delle torri civiche iniziarono a suonare l'Ave Maria mezz'ora dopo il tramonto del Sole, all'imbrunire, nel momento coincidente con l'effettivo termine della luminosità diurna, che era attentamente seguito dalla popolazione per la recita dell'Angelus.

Nel sistema ad ore italiche il conteggio del tempo diurno iniziava al tramonto del Sole, dal quale si numeravano ventiquattro ore fino al tramonto successivo.

L'orologio italico vede gli inizi del suo impiego verso la metà del I 300; il suo vantaggio principale era di semplificare il calcolo delle ore di luce residue semplicemente sottraendo l'ora segnata sul quadrante dalle ventiquattro totali in cui era diviso il giorno. L'oscurità rappresentava, infatti, il pericolo più temuto dai popoli antichi: i pastori temevano di attardarsi al pascolo e perdere nell'oscurità i capi di bestiame, i contadini necessitavano di rincasare dai campi, i mercanti preferivano riportare le merci nelle proprie dimore extra moenia in salvo da briganti e predoni altrimenti favoriti nelle ruberie dalla densa oscurità.

"Questo modo di contare le ore si diffuse moltissimo in Italia, perciò vennero chiamate ore italiane, ore all'italiana" [Papalini 20I I, pp. 248-254].

L'inconveniente fondamentale era determinato dalla variabilità dell'orario del tramonto, con la conseguente impossibilità di associare il mezzogiorno astronomico a un'ora fissa, come invece accadeva con l'ora sesta nel precedente sistema ad ore diseguali adottato dai greci e dai romani.

La volontà di restituire al Chiostro grande il suo antico orologio solare ha determinato la necessità di disegnare un nuovo reticolo del tempo che potesse funzionare correttamente in relazione allo gnomone esistente; il dipinto del Carelli ha definito la scelta di ripristinare l'antico sistema orario all'italiana, sebbene oggi in disuso.

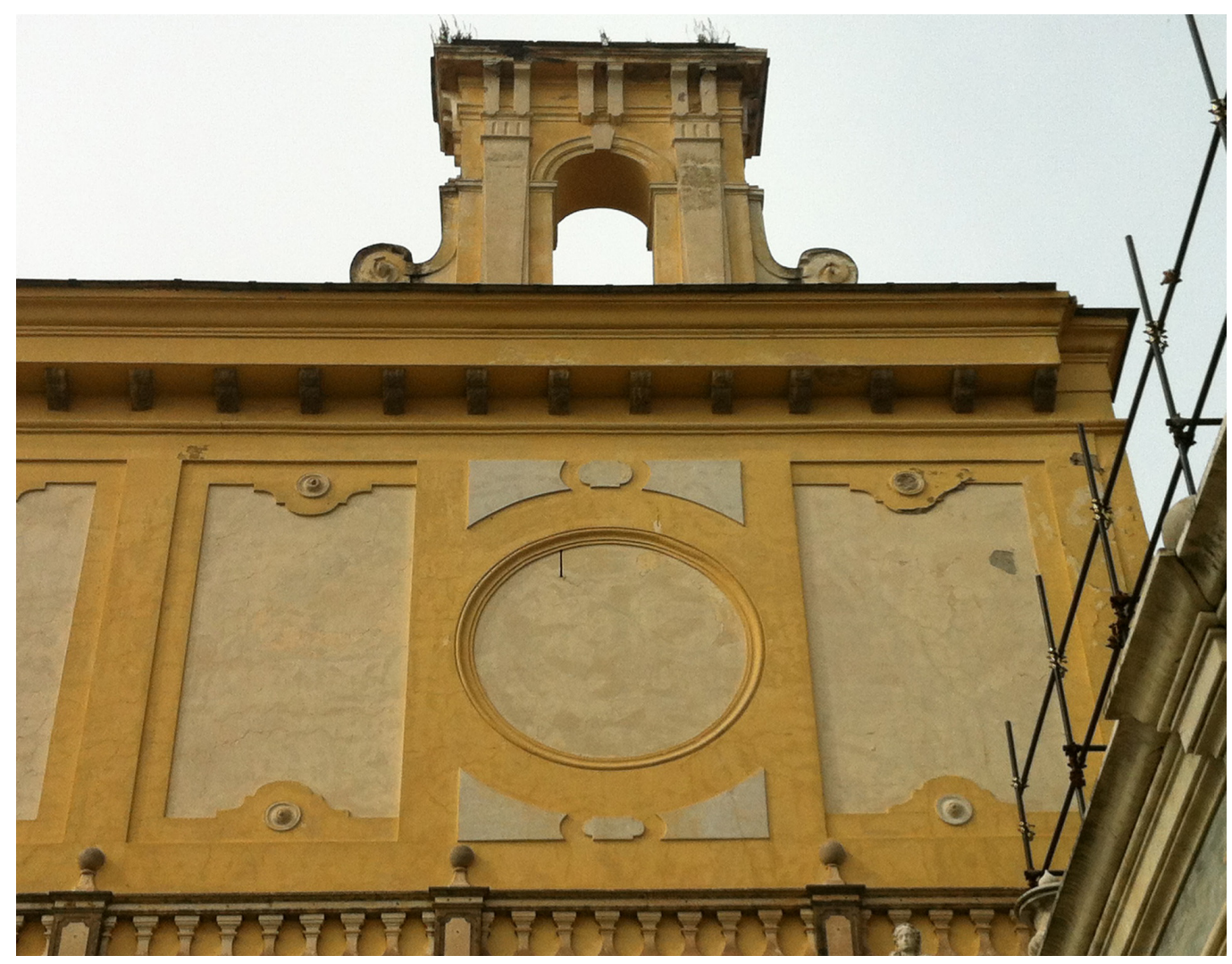




\section{II rilievo per il restauro}

II rilievo dell'orologio solare è stato condotto mediante tecniche miste volte alla determinazione della corretta giacitura della parete rispetto ai punti cardinali e alla definizione dell'esatta lunghezza e posizione dell'ortostilo. Sono stati effettuati prelievi diretti di misure in situ, fotoraddrizzamenti e rilievi indiretti, mediante fotogrammetria digitale basata sulla tecnica SfM [5]: la misura precisa dell'ortostilo rilevato è pari a $40 \mathrm{~cm}$, mentre la 'declinazione gnomonica' [6], risulta pari a un angolo di $75^{\circ}$ est. II quadrante si definisce declinante di $75^{\circ}$ verso est poiché offre la sua superficie ai raggi provenienti da Oriente a causa dell'angolo antiorario (di $75^{\circ}$ ) di cui è ruotato rispetto alla giacitura est-ovest che si assume come declinazione nulla. La misura $\delta$ della declinazione gnomonica della parete è stata inoltre verificata dai rapporti geometrici riscontrati in fase di rilievo, in particolare al mezzogiorno dell'equinozio di primavera. L'analisi geometrica dell'impianto proiettivo a seguito del rilievo ha inoltre evidenziato la presenza di alcuni triangoli rettangoli particolarmente utili per il tracciamento delle linee diurne grazie agli angoli interni noti di valore pari alla latitudine $(\lambda)$, alla co-latitudine $(B)$ e alla declinazione gnomonica $(\delta)$.

Mediante scialbatura superficiale dello strato di pittura è stata ritrovata la presenza di brevi tratti dell'originario reticolo orario dipinto, che hanno confermato i colori rosso e blu ritratti dal Carelli, senza però fornire sufficienti indicazioni circa l'andamento geometrico delle linee, ormai completamente cancellate, ad eccezione di lievi tracce intorno alla base dello gnomone.

\section{Geometrie della luce per la gnomonica}

Nel campo della gnomonica si assume la centralità del nostro pianeta all'interno di un modello geometrico di studio, che esemplifica il moto apparente del Sole. La Terra viene collocata nel centro di una concentrica sfera celeste ideale, il cui diametro può essere arbitrariamente assegnato poiché il modello proiettivo è centrale e si basa su una stella di rette passanti per il centro della sfera che opera con processi geometrici equivalenti per tutte le possibili e infinite sfere concentriche. Lungo tale superficie si immaginano collocati gli astri, ciascuno con il suo rispettivo movimento apparente, diurno e annuale. II Sole, ad esempio, ogni giorno traccia un arco di circonferenza, la cui lunghezza dipende dal periodo dell'anno. Gli archi hanno tutti la medesima giacitura, che varia in funzione della latitudine del luogo (misurata rispetto allo zenit) e dunque sono circonferenze parallele, di diametro massimo

Fig. 4. La declinazione gnomonica della facciata principale del Chiostro grande.
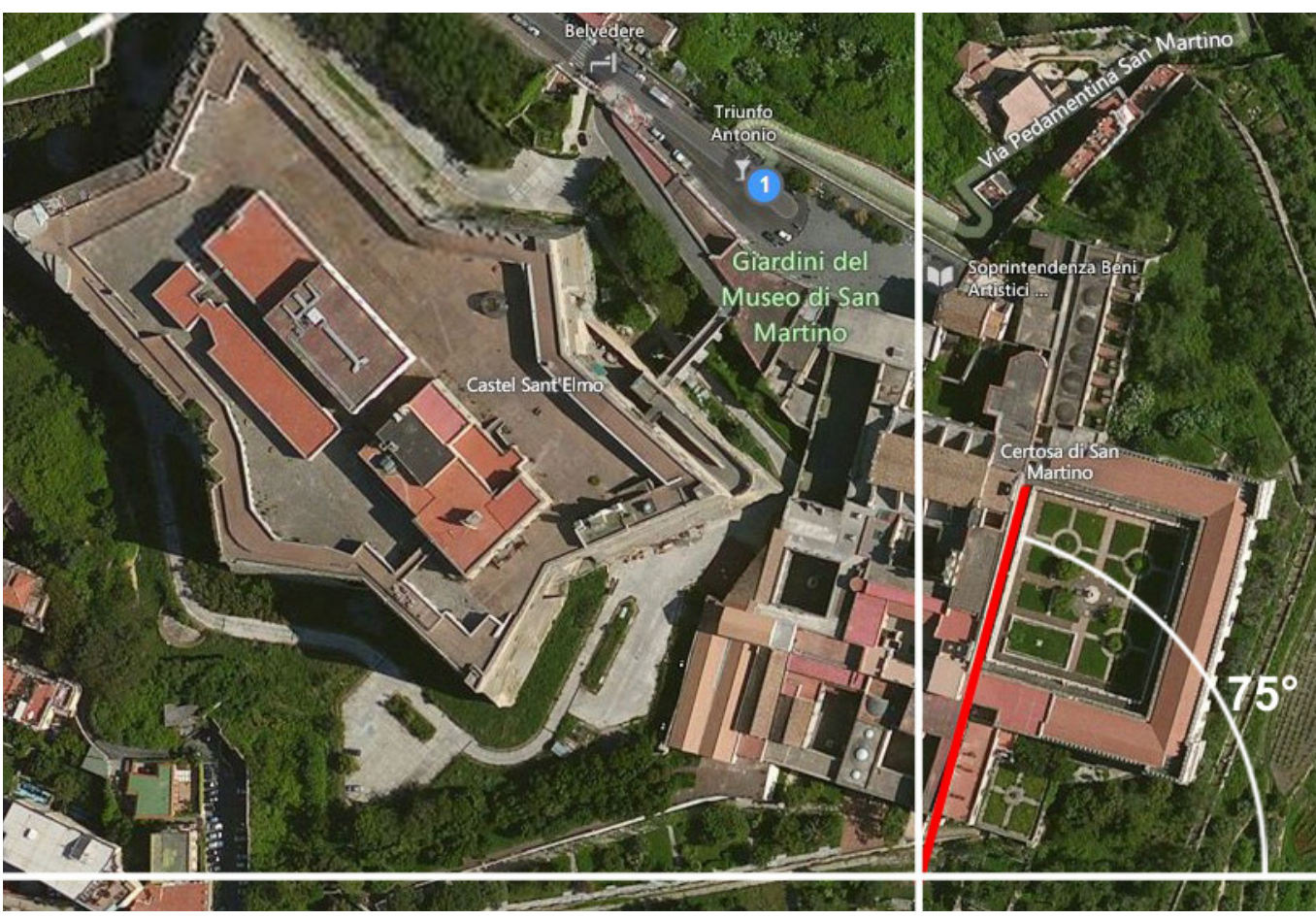
solo in coincidenza delle date degli equinozi, nei quali la curva coincide con i due giorni con lo stesso numero di ore di luce e di oscurità, precisamente il 21 marzo (equinozio di primavera) e il 23 settembre (equinozio di autunno). Nei quadranti solari altre due date risultano sempre rappresentate e sono quelle del 2 I giugno (solstizio d'estate) e del 21 dicembre (solstizio d'inverno), giorni in cui il numero delle ore di luce, ovvero il tempo in cui il Sole si trova al di sopra dell'equatore celeste, è rispettivamente massimo e minimo.

Quando lo studio del moto apparente del Sole è finalizzato alla gnomonica, si assume che la punta dello gnomone coincida con il centro dell'intero sistema proiettivo, poiché per tale estremità passeranno le stelle di rette formate dai raggi luminosi, la cui intersezione con la superficie del quadrante determina le linee, sia orarie che diurne, deputate a relazionare ciascuna ombra alla corrispondente misura del tempo.

II ripristino dell'antico tracciato delle linee del tempo ha richiesto il disegno del modello 3D di una sfera celeste, con le posizioni del Sole nel conteggio orario all'italiana: sono state individuate le circonferenze diurne [7] e quelle orarie. Le prime sono le direttrici simmetriche del cono di luce avente vertice nello gnomone, le cui intersezioni determinano sul quadrante le curve diurne dei due solstizi. È la rappresentazione del tempo ciclico (Aion), che ritorna nella successione delle stagioni: si noti che la forte declinazione della parete ha determinato una forma delle iperboli solstiziali sensibilmente diversa da quella denotata nella figura I (l'orologio presenta $\delta=\mid 8.6^{\circ} \mathrm{E}$ ) ma soprattutto differente da quella riportata nei quadranti non declinanti $\left(\delta=0^{\circ}\right)$ che presentano le iperboli solstiziali con asse trasverso perfettamente verticale.

Sulla sfera cono state tracciate anche le circonferenze orarie nel sistema italico e l'intersezione di ciascun piano orario con la superficie della parete determina la corrispondente retta oraria, una successione di tempo cairologico che, nell'orologio della Certosa, è compresa nell'intervallo che va dall'ora dodicesima alla diciannovesima [8].

In analogia con quanto ritratto dal Carelli, il cui quadrante non riportava alcun motto, le linee diurne sono state ridipinte in rosso, calibrando lo spessore del tratto (circa $2 \mathrm{~cm}$ ) sulla dimensione delle tracce di colore ritrovate. Per garantire l'ottimale leggibilità dell'orologio, mediante simulazioni digitali delle condizioni luminose, è stato verificato che la linea avesse

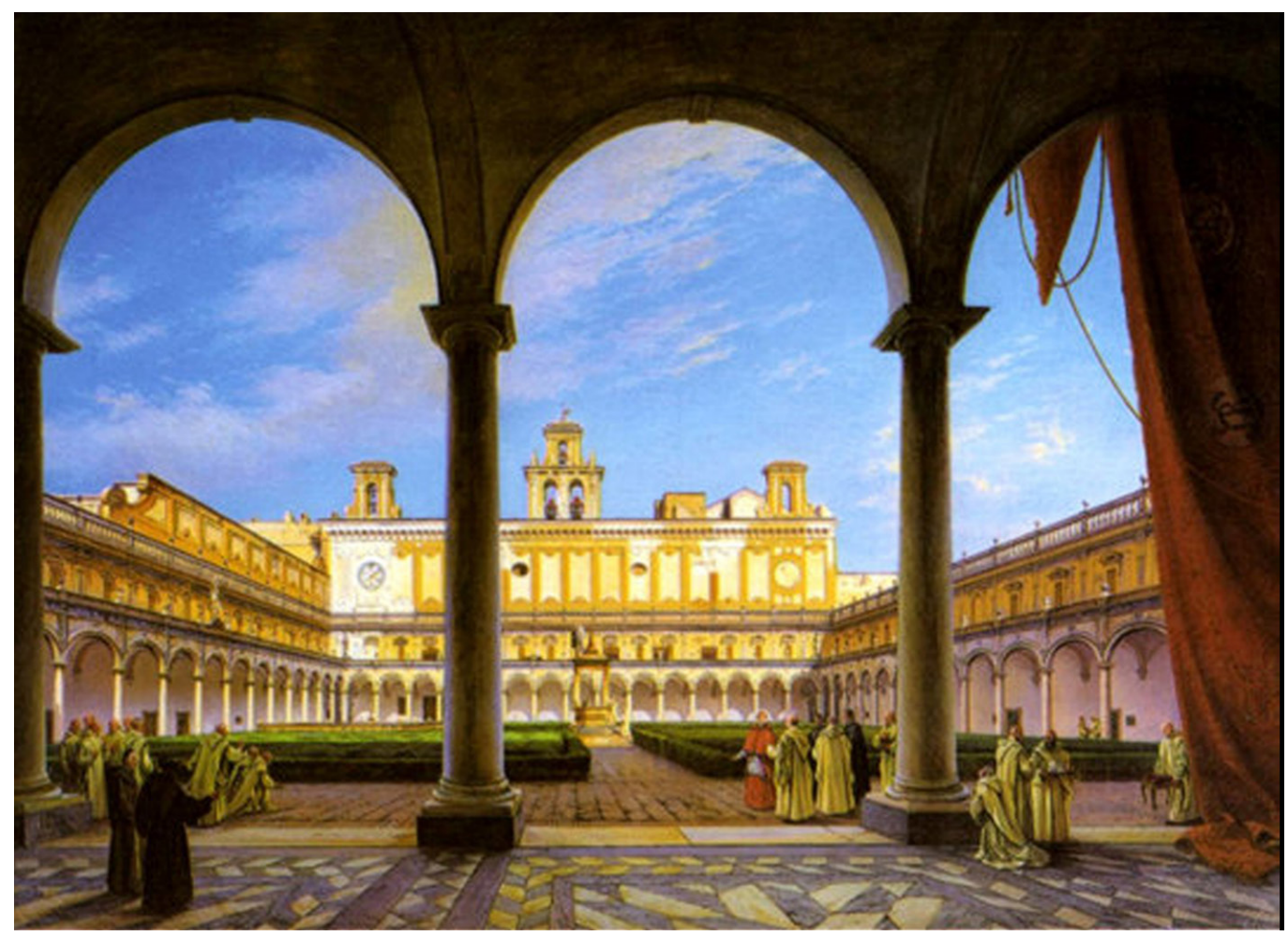


Fig. 6. La sfera celeste per la città di Napoli, $\lambda=$ latitudine.

Fig. 7.Verifica geometrica delle misure lineari angolari rilevate sul quadrante solare.

Fig. 8. Determinazione delle iperboli diurne cor rispondenti ai due solstizi metodo dei coni luminosi, assonometria.

Fig. 9. Determinazione delle iperboli diurne cormetodo dei coni luminosi, prospetto.
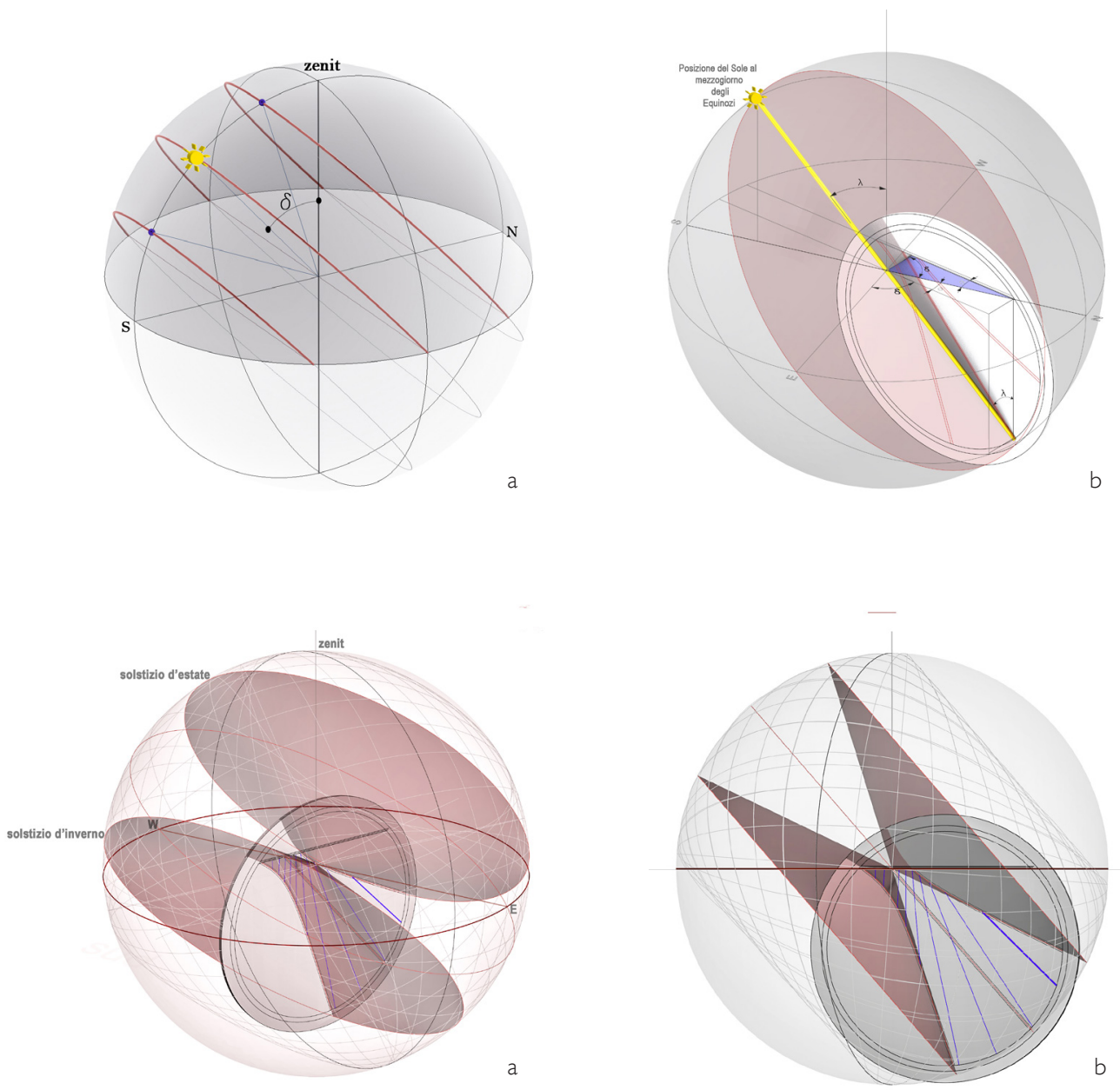

Fig. 10. Determinazione della retta oraria sedicesima come intersezione tra la superficie del quadrante e il piano orario italico corrispondente.

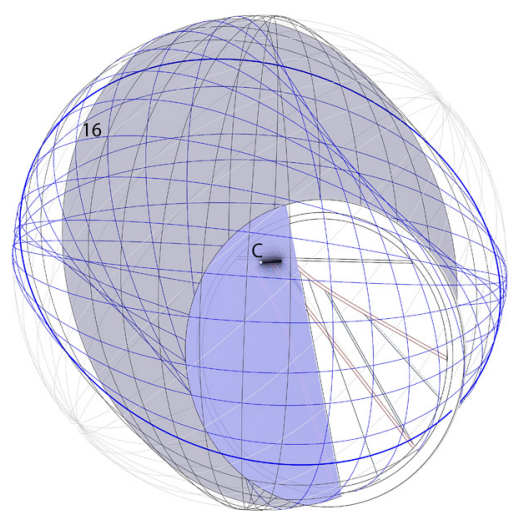


Fig. I I. L'orologio solare restaurato, 2018. Dettaglio dello gnomone e delle curve del tempo restaurate.

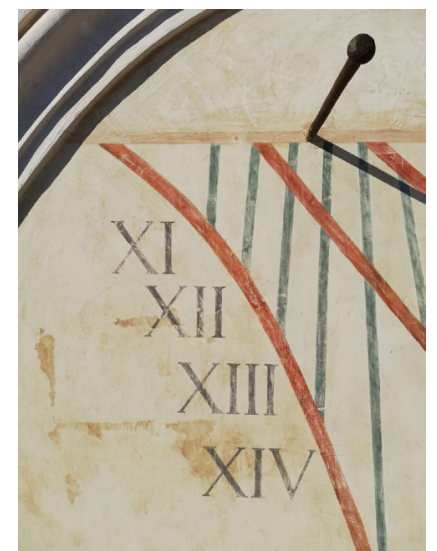

comunque una larghezza maggiore dell'ombra proiettata dallo gnomone e che, nelle numerose viste prospettiche di un osservatore collocato nel Chiostro, il carattere tipografico dei numeri da apporre accanto a ciascuna linea oraria, scelto in analogia con quelli presenti nell'adiacente orologio meccanico, potesse essere nitidamente visibile [9].

\section{Conclusioni}

A dispetto del valore scientifico e artistico, numerosi orologi solari di pregevole valore non sono adeguatamente conservati né valorizzati per il progressivo disperdersi di questa antica cultura millenaria.

II taglio metodologico della presente ricerca intende ribadire l'importanza (e l'urgenza) di riportare la disciplina gnomonica in seno alle conoscenze del disegno e della geometria, che in origine resero misurabile sulla Terra ciò che appariva incommensurabile in cielo. La gnomonica necessita oggi di essere riletta mediante le discipline delle sue radici originarie, dopo circa due secoli di specialismi e/o astrattismi analitico-matematici che ne hanno determinato una progressiva dispersione. II disegno, la geometria e il rilievo devono rivendicare il loro ruolo di strumenti necessari e indispensabili per interpretare e coordinare le valenze provenienti dai diversi campi del sapere che convergono nella progettazione e nella realizzazione di un orologio solare, con il fine ultimo della valorizzazione, basato su un'opportuna azione di conoscenza e di conservazione, attraverso restauri consapevoli.

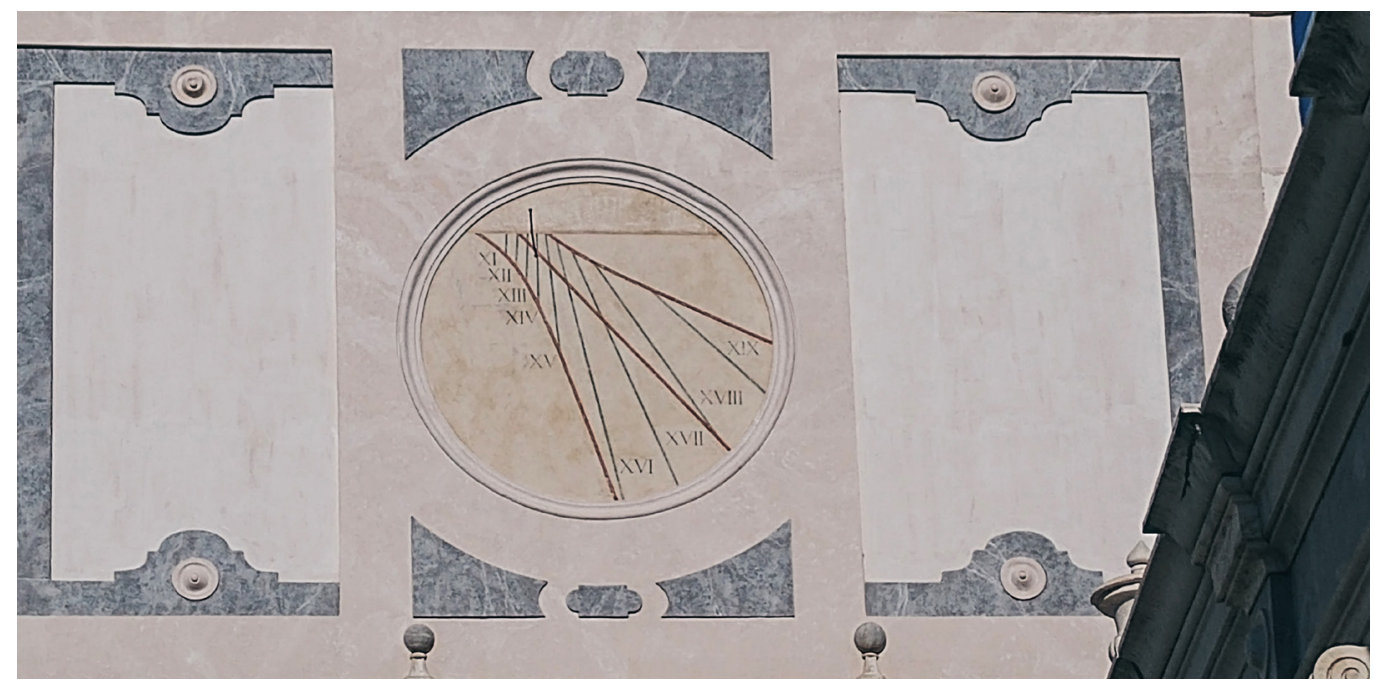




\section{Note}

[I] II restauro dei quattro monumentali orologi solari dell'astronomo Giuseppe Cassella è stato di recente concluso dalla Fondazione Carditello. Progetto di restauro e ripristino della funzionalità gnomonica: Alessandra Pagliano. Lavori di restauro: Eugenio Loreto con Struere soc. coop.

[2] (Tempus) nec cessat nec errat: (II tempo) non si ferma né sbaglia.

[3] Si tratta di antichi orologi meccanici che regolavano l'azionamento delle campane in corrispondenza delle ore italiche. Dotati di un'unica lancetta, questo orologi avevano un quadrante scandito solo da 6 frazioni orarie e dunque la lancetta faceva quattro giri completi nell'arco diurno.

[4] II sistema cronometrico ad usum campanae altro non è che quello ad ore italiche spostato di mezz'ora per far coincidere l'ora ventiquattresima con l'imbrunire. II nome trae la sua origine dalla funzione di regolare l'attività delle campane.

[5] La tecnica SfM, Structure from Motion, basata su algoritmi della ComputerVision, estrae i punti omologhi riconoscibili su due o più foto, rilevandone le coordinate nello spazio.

[6] La declinazione gnomonica di una parete verticale, da non confondersi con le omonime coordinate celesti del Sole, è la misura in gradi dell'angolo formato dalla traccia del piano verticale della facciata sull'equatore celeste, rispetto alla direzione cardinale $\mathrm{E}-\mathrm{W}$, misurata in verso antiorario.

[7] Le curve diurne sulla sfera celeste sono comuni, sulla sfera celeste, a tutti i sistemi cronometrici.

[8] Quando l'ombra tocca, ad esempio, la linea della tredicesima ora, bisogna intendere che sono già trascorse tredici ore dall'ultimo tramonto e dunque ne mancano undici al successivo, evidenziando in tal modo quante ore di luce sono ancora a disposizione nell'arco temporale della giornata.

[9] II carattere tipografico scelto ha l'altezza di $10 \mathrm{~cm}$.

\section{Riferimenti bibliografici}

Amodeo Federico (1924). Vita matematica napoletana. Parte seconda. Napoli: Accademia Pontaniana.

Ceravolo Tonino (2006). I monaci di clausura. Soveria Mannelli: Rubbettino editore.

D’Anna Nuccio (1999). Il gioco cosmico. Tempo ed eternità nell'antica Grecia. Roma: Edizioni mediterranee.

De Lucia Vincenzo ( I83I). Elementi di Cosmografia e di Cronologia. Napoli: Stamperia de' Fratelli Criscuolo. I

Fittipaldi Teodoro, Casolaro Renato (1995). II museo di San Martino a Napoli. Napoli: Electa.

Galimberti Umberto (2016). Psiche e techne: l'uomo nell'età della tecnica. Milano: Feltrinelli (9 edizione).

Lalande Jérôme (1769). Voyage d'un françois en Italie, fait dans les annue 1765 et 1766. Venice: Chez Deassaint.

Mandelli Emma, Lavoratti Gaia (a cura di), (20l0). Disegnare il tempo e l'armonia. Il disegno di architettura osservatorio nell'universo. Firenze: Alinea editrice. Firenze.

Pagliano Alessandra, Murolo Roberta, Santoro Luca (20l4). Disegnare il tempo. Rocco bovi e gli orologi solari della Certosa di San Martino. Roma: Aracne editrice.

Pagliano Alessandra (20।8). Le ore del Sole. Geometria e astronomia negli antichi orologi solari romani. Napoli: Editori Paparo.

Paltrinieri Giovanna (2005). Meridiane e orologi solari d'Italia, con la prefazione di M. Hack. Roma: l'Artiere.

Paradiso Della Monica Giuseppe, Guglielmelli Maria Rosaria (a cura di), (2000). Arenella e dintorni. Napoli:Arte tipografica.

Penta Maria Teresa, Jatta Barbara (2002). Incisioni del '700 in Italia: nella raccolta d'arte Pagliara dell'Istituto Suor Orsola Benincasa. Napoli: Istituto Suor Orsola Benincasa.

Philippson Paula (1949). II concetto greco di tempo nelle parole Aion Chronos Kairos Eniautos. In Storia della filosofia, n. 4, I949, pp. 81-97.

Severino Nicola (2006). L'orologio multiplo della Certosa di San Martino a Napoli: nuove ipotesi e considerazioni. <http://umw.nicolaseverino.it>.

Spinosa Nicola (2000). San Martino immagini e memorie. Napoli: Grimaldi \& C. Editori.

Zaccaria Ruggiu Annapaola (2006). Le forme del tempo: Aion, Chronos, Kairos. Padova: Il poligrafo.

Autore

Alessandra Pagliano, Università di Napoli "Federico II", alessandra.pagliano@unina.it

Per citare questo capitolo: Pagliano Alessandra (2020). La gnomonica antica tra arte e scienza: geometria, storia e astronomia per il restauro dell'orologio solare della Certosa di San Martino/The ancient gnomonics between art and science: geometry, history and astronomy for the restoration of the sundial in the Charterhouse of San Martino. In Arena A., Arena M., Brandolino R.G., Colistra D., Ginex G., Mediati D., Nucifora S., Raffa P. (a cura di). Connettere. Un disegno per annodare e tessere. Atti del $42^{\circ}$ Convegno Internazionale dei Docenti delle Discipline della Rappresentazione/Connecting. Drawing for weaving relationships. Proceedings of the 42th International Conference of Representation Disciplines Teachers. Milano: FrancoAngeli, pp. 732-751. 


\title{
The Ancient Gnomonics between Art and Science: Geometry, History and Astronomy for the Restoration of the Sundial in the Charterhouse of San Martino
}

\author{
Alessandra Pagliano
}

Abstract

In the ancient Greek world there are three interesting representations of the concept of Time, each associated to a specific iconographic form. A sundial, as a drawing of time and space in which the apparent motion of the Sun takes place, presents a set of curves, straight lines, symbols and inscriptions that can be associated to the three Greek figures of Time. In spite of their scientific and artistic value, many sundials are not adequately preserved and valued for the progressive dispersion of this ancient culture.

This contribution illustrates the geometrical method adopted to restore to the Great Cloister of the Certosa di San Martino in Naples its ancient sundial for which it was necessary to draw a new grid of time that could function correctly in relation to the existing gnomon; on the basis of information provided by a painting by $\mathrm{G}$. Carelli, it was decided to restore the ancient Italian-style time system, although now in disuse.

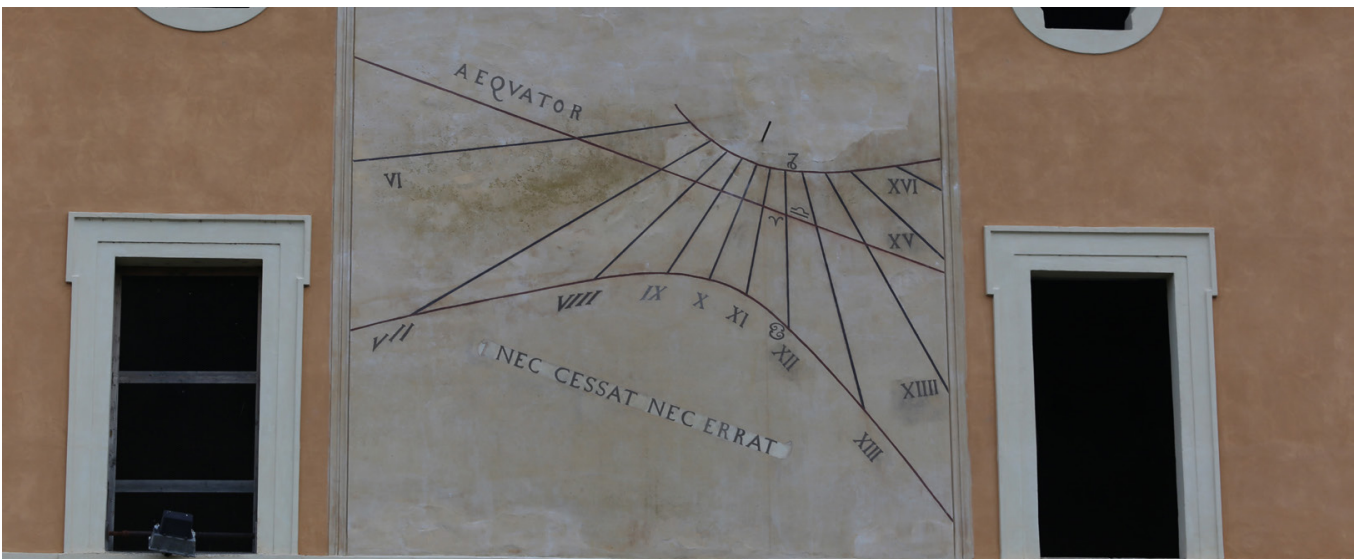




\section{Sundials as a representation of time through the myth of Cronos, Aion and Kairos}

The measurement of time has been, for thousands of years, one of the fundamental cognitive organizers, together with the concept of space, for the description and interpretation of natural phenomena. In primitive peoples it was a need directly linked to survival: in the evolutionary phase of hunter-gatherer, man felt the need to identify midday, an imaginary boundary between morning and afternoon that allowed to program activities, avoiding the risk of to be surprised by the darkness, far from the refuge.

The problem of time measurement was therefore linked to its daytime cycle. When man became a farmer, because inducing significant transformations in territories, it was necessary to understand and measure the seasonal events' duration, whose alternation and cyclical return had to be predicted in order to plan all the needed actions to prepare the soil for sowing or harvesting. The first interpretations of astronomical phenomena visible to the naked eye were based on evidence that the stars and planets made regular cyclical motions when observed from the Earth in a stationary position. The indisputability of such observations led to the formulate the philosophical-religious idea that the Man was the center of the Universe.The most important ancient cosmological models were therefore geocentric. Ancient Egyptians and the Babylonians reached a knowledge's level in astronomy which is still surprising today, but the corresponding scientific model of the Universe was seriously instilled with mythological elements.

In ancient Greece, the concept of time was the subject of philosophical dissertations about its dual nature of perpetual dimension (characterized by uninterrupted cyclicity) and, at the same time, of temporary, fleeting and changeable phenomenon. Each moment, therefore, represents a fragment of eternity.

Greeks had three interesting representations of Time, each associated with a specific iconographic form.

Chronos, progressively assimilated to the mythological figure of the titan Kronos (Koóvos) and later to Saturn, is time as a succession of instants, hours, days, that is the time that flows and devours existence. A representation, in other words, of the infinite number of following (and escaping) moments. According to Galimberti "man dwells in what Prometheus called 'aging time' and which, as he grows older, lays even more bare the condition of 'mortal [brótos]' to which men are hopelessly consigned and from which Prometheus had tried to defend them by placing in them 'blind hopes'" [Galimberti 2019, p. I48].

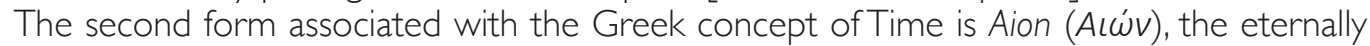
cyclical and fertile time linked to nature, who holds the wheel of the Zodiacal signs, representing the seasonal cycle. The juxtaposition of Aion with the annual cycle of the Sun, but also with the Phoenix, symbol of rebirth from death, underlines the eternal cyclicity of time: "L'accostamento Aion/Fenice ci introduce in una nuova prospettiva, che non solo sviluppa il simbolismo del Sole in connessione con il tempo sempre identico a sé stesso, ma ne traduce le aspettative di rinnovamento periodico secondo un simbolismo ciclico tra i più diffusi. La Fenice è, infatti, per eccellenza il simbolo della renovatio temporum" [D'Anna 199, p. I48].

Finally, there is Kairos (Kaıpós), the fleeting time, the single instant, the propitious moment, the opportunity to be seized. It represents the constant mutability and, therefore, the "quality' of Time, i.e. the individual peculiarity of each single instant, when subtracted from the abstract flow of infinite equal moments. The concept of cairological time is opposed to the chronological one, which is more usual for us, since it does not consider time in its linear and measurable development, but the moment of the propitious occasion, the 'right time' to be able to seize to perform an action.

Sundial, as a representation of time and space in which the apparent motion of the Sun takes place, present a set of curves, straight lines, symbols and inscriptions that can be associated with the three Greek figures ofTime.

The line grid of a vertical sundial is divided into daily and hourly curves: the former (hyperbolic in shape) correspond to the path of the shadow cast by the gnomon on a given day. Traditionally, at least three are always present, corresponding to the remarkable dates in the calendar that mark the passage between seasons. The hyperbola close to the gnomon 

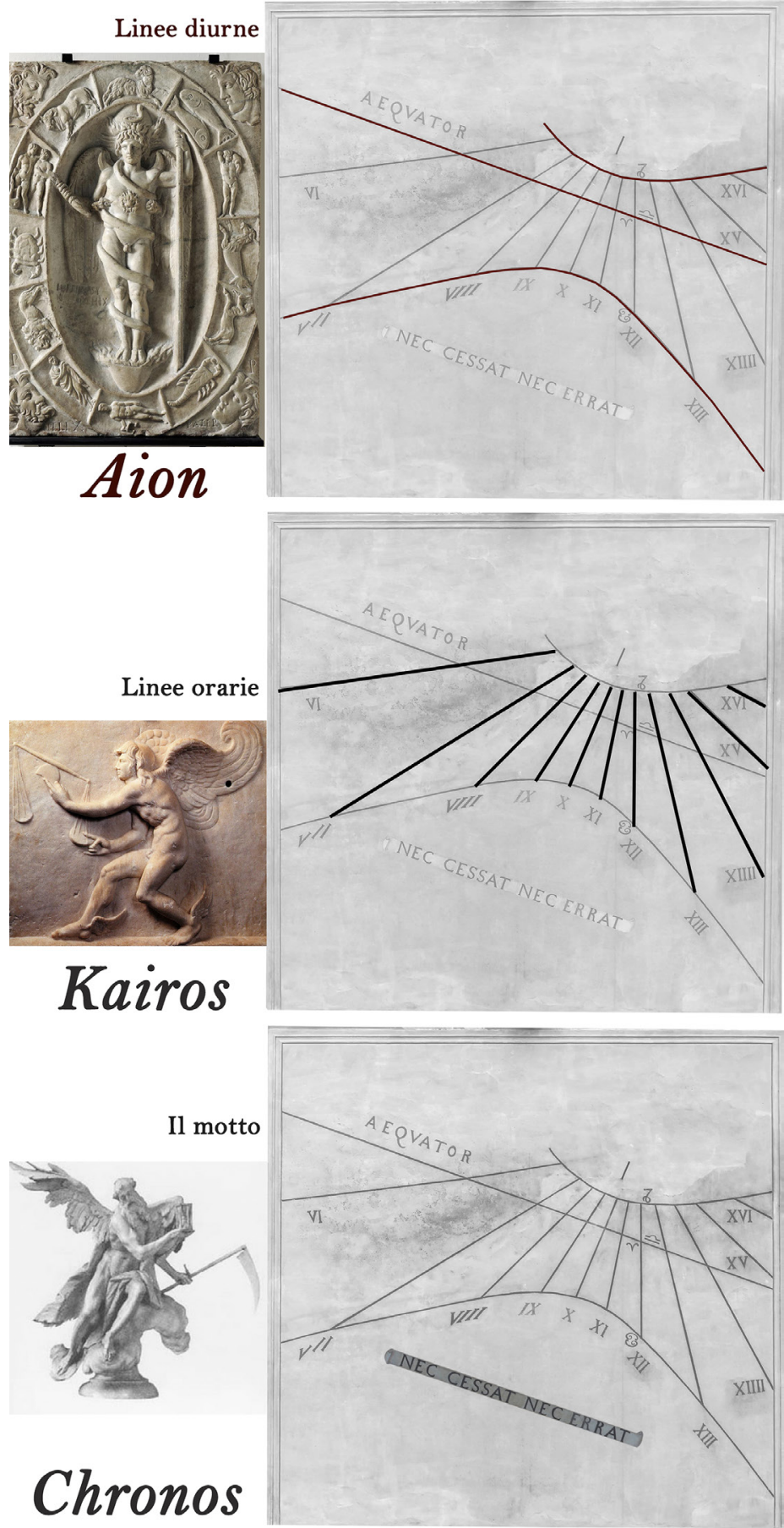
identifies the day of the winter solstice, while at the opposite end of the grid there is the summer solstice hyperbola. In a central position, between these curves, there is a straight line in which 21 March and 23 September (the spring and autumn equinoxes respectively) coincide. We can assert that the diurnal curves represent the concept of natural cyclic time impersonated by Aion. The cairological time, on the other hand, is drawn by the hour lines, different for each chronometric system and characterized by the constant diurnal mutability of the gnomon's shadow due to the Earth's rotation motion. At last, most sundials, starting from the 16th century, present an engraved or painted 'motto', usually a memento mori or a wise consideration about human life's transience, which we can we can associate chronological time to, because it underlines the mortality of human condition. Figures I show one of the four monumental sundials, recently restored [I] at the Real site of Carditello (CE). The sundial motto is Latin, nec cessat nec errat [2]: it's painted in the festoon and refers to upper sundial as a representation of Time (Chrono), through its gnomonic projection in the line grid. In red are highlighted the daily curves between seasons that measure the cyclic alternation of natural phenomena (Aion) while in black are painted the hour lines (Kairos), according to the French chronometric system, that measures the daytime time in twenty-four hours, starting at midnight.

\section{The restoration of the vertical sundial of the Great Cloister of the Charterhouse of San Martino}

Along the main facade of the Great Cloister there are two ancient circular dials. On the right side there is a mechanical 'six-hour' [3] clock and, in a symmetrical position, there is a vertical sundial, also circular and ofathe same diameter. The façade has an orientation that exposes the gnomon's tip the to eastern and south-eastern Sun's rays: this orientation, defined as the "gnomonic declination of the wall" (d), allows the gnomon to cast its shadow from dawn until noon, leaving the sundial inactive in the afternoon. For about a century, the original gnomon in the wall was all that remained of this monumental sundial.

It consists of a metal rod, with a rounded tip, which perpendicularly protrudes $40 \mathrm{~cm}$ from the wall and, therefore, takes the term 'orthostyle'.

Some historical photos testify that in 1910 the sundial's lines were already illegible: the fast fading of the only painted and not engraved signs but, above all, the abandonment of the Italic hours in favour of the French system, have certainly determined the progressive obli-

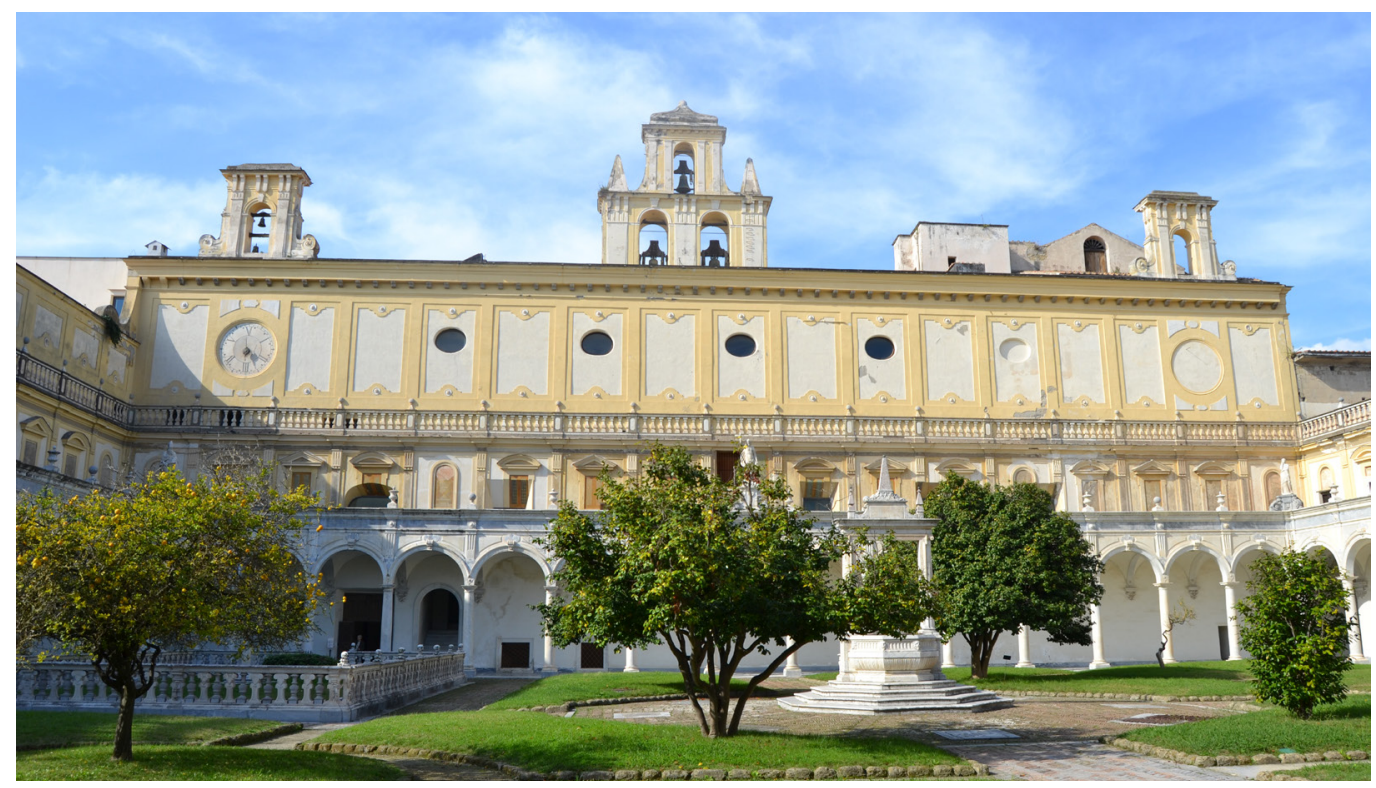


vion of the sundial. A painting by Gabriele Carelli, entitled The Great Cloister of the Carthusian monastery of San Martino (1853), depicts an interior view in which both clocks appear in detail. However, it is not possible to state whether the time system was the Italic one or the similar one called ad usum campanae [4], which appeared in Italy some centuries after it, when the bells began to ring the Ave Maria half an hour after sunset, at dusk, or the moment coinciding with the end of daylight, which was closely waited by the population for the recitation of the Angelus.

In the Italic-hour system, the daytime counting started at sunset, from which the day was divided into twenty-four hours until the next sunset. The Italic sundial began to be used in the mid I300s; its main advantage was to simplify the calculation of the remaining number of sunlight by simply subtracting the time marked on the dial from the total twenty-four, into which the day was divided. The darkness represented, in fact, the most feared danger by the ancient peoples: the shepherds feared to linger in the pasture and lose their cattle in the darkness, the farmers needed to get back from the fields, the merchants preferred to bring the goods back to their homes, generally extra moenia, safe from brigands, otherwise favored in the robberies by the darkness.

"Questo modo di contare le ore si diffuse moltissimo in Italia, perciò vennero chiamate ore italiane, ore all'italiana" [Papalini 20I I, pp. 248-254].

The fundamental inconvenience was determined by the sunset's variability, day by day, with the consequent impossibility to associate the astronomical noon with a fixed hour, like the sixth hour in the previous system, adopted by ancient Greeks and Romans. In a symmetrical position to the mechanical clock there is a vertical sundial, also circular and of equal diameter.

The intention to give back to the Great Cloister its ancient sundial determined the need to draw a new time grid that could work correctly in relation to the existing gnomon; Carelli's painting defined the choice of restoring the ancient Italian-style time system, although now in disuse.

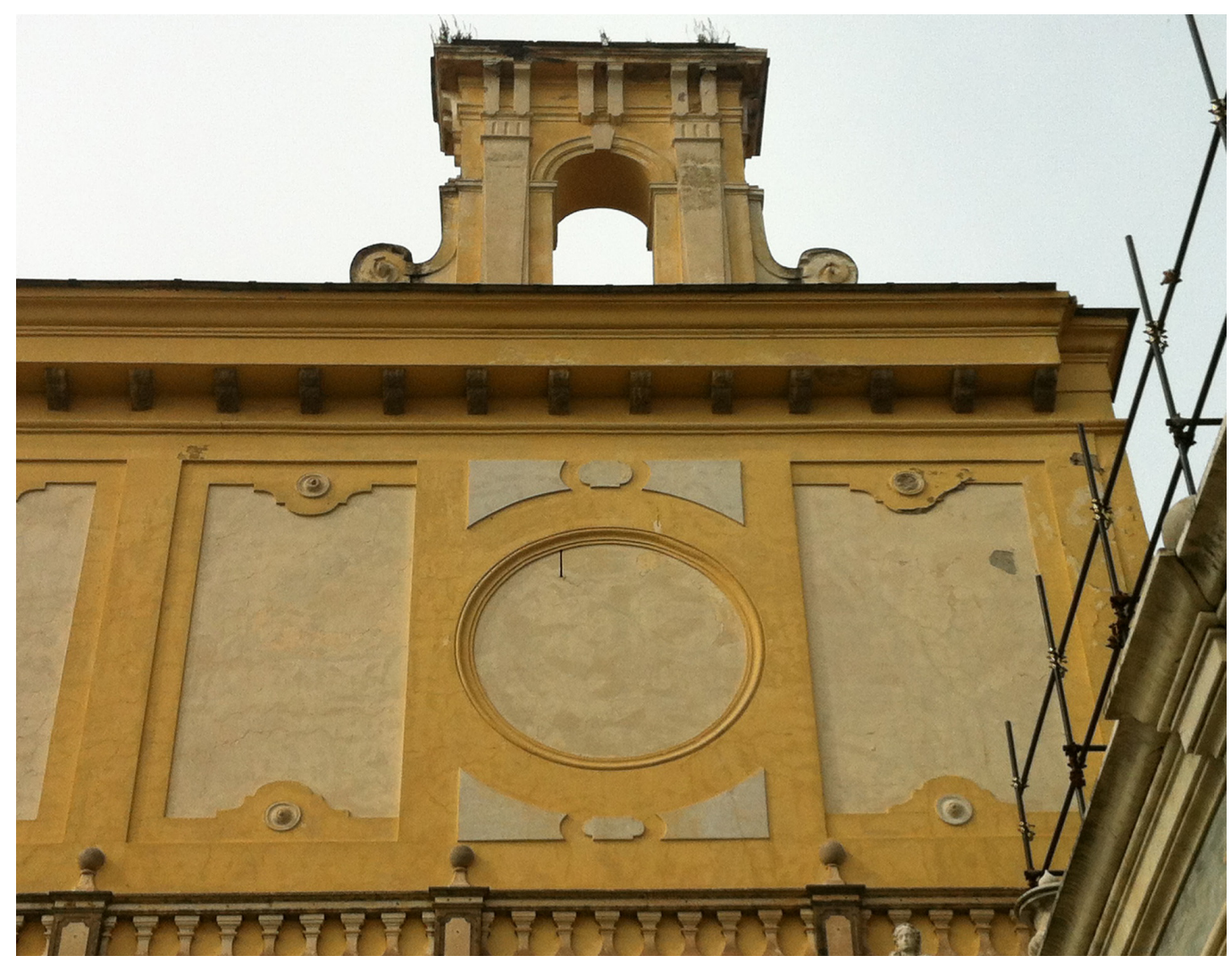




\section{Surveying for restoring}

In order to survey the remaining sundial we adopted mixed techniques aimed at determining the correct position of the wall with respect to the cardinal points and defining the exact length and position of the orthostyle. Direct in situ measurements, photo-straightening and indirect measurements were taken using digital photogrammetry based on the SfM technique [5]: the precise measure of the gnomon is $40 \mathrm{~cm}$, while the 'gnomonic declination' [6] of the facade is equal to an angle of $75^{\circ}$ east.

A sundial is defined as declining $75^{\circ}$ eastwards when its surface faces to the rays coming from the East; it means that the façade is rotated of an angle of $75^{\circ}$ with respect to the eastwest position which is assumed as null declination. The gnomonic declination of the wall $\left(\delta=75^{\circ}\right)$ was also geometrically verified, particularly testing the correct survey measurement at noon of the spring equinox. The geometrical analysis of the whole projective system obtained from the survey has also highlighted the presence of some rectangular triangles, particularly useful for tracing diurnal lines thanks to the already known angular value of internal angles, equal to latitude $(\lambda)$, co-latitude $(B)$ and gnomonic declination $(\delta)$. By means of the superficial shaving, we found the presence of short traces of the original painted hour grid, which confirmed the red and blue colours portrayed by Carelli, but without providing any other information about the geometric pattern of the lines, completely erased, with the exception of slight traces around the base of the gnomon.

\section{Light geometry for gnomonics}

In the field of gnomonics we assume the centrality of the Earth within a geometrical model of study, which exemplifies the apparent motion of the Sun. The Earth is placed in the center of an ideal concentric celestial sphere, whose diameter can be arbitrarily assigned because the projective model is central and is based on a star of straight lines passing through the center of the sphere that operates with equivalent geometric processes for all possible and infinite concentric spheres. Along this surface all the stars are placed, each with its respecti-
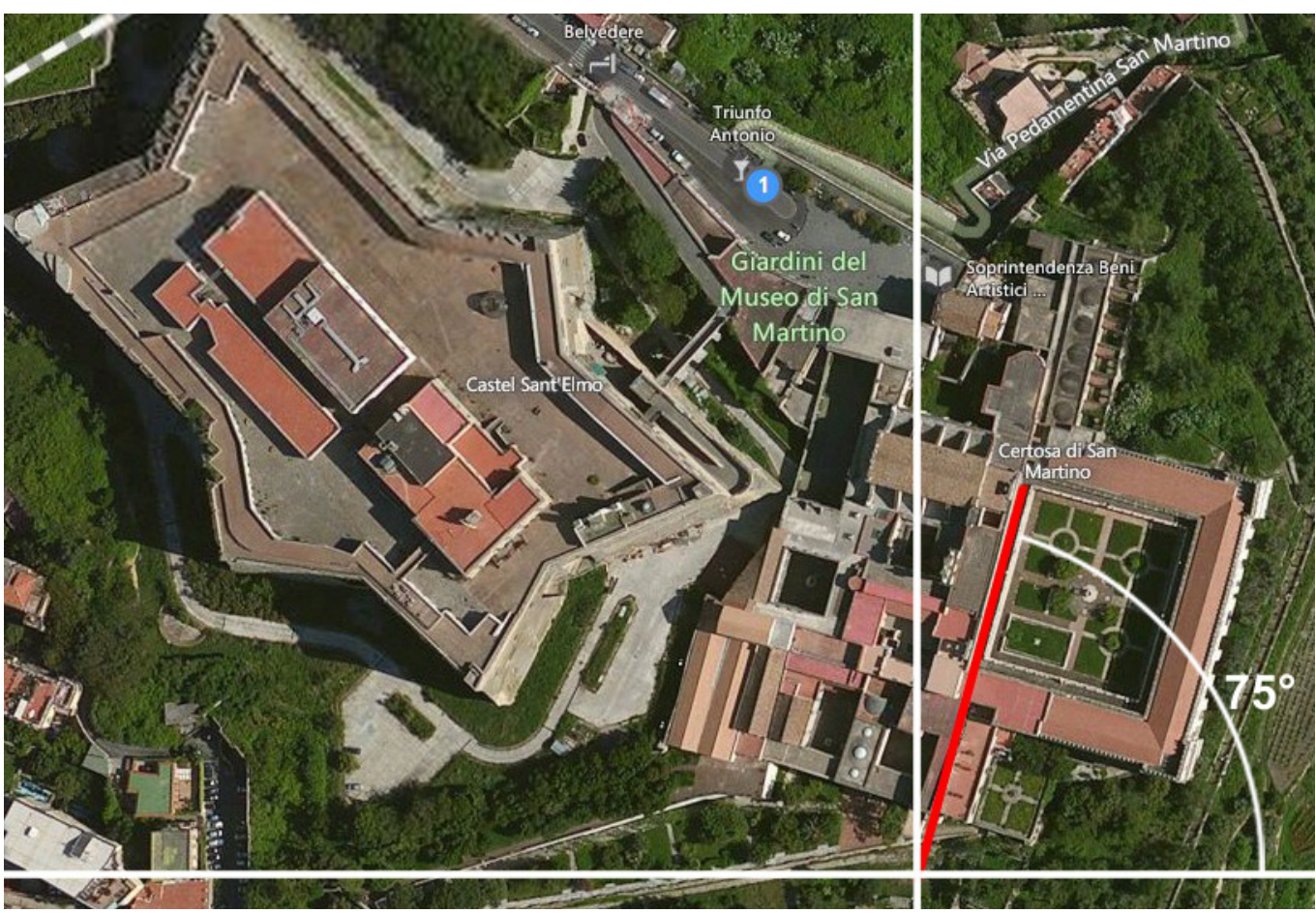
ve apparent movement, diurnal and annual. The Sun's daily path, for example, is an arc of circumference, the length of which depends on the period of the year.The arcs all have the same position, which varies according to the latitude of the place (measured with respect to the zenith) and therefore are parallel circumferences, of maximum diameter only at the equinoxes, when the circumference is cut in half by the equator because there are the same number of hours of light and darkness, precisely on March 21 (spring equinox) and September 23 (autumn equinox). In the sundials two other dates are always represented: June the 2 Ist (summer solstice) and December the 2 I st (winter solstice), days when the number of hours of light, that is the time when the Sun is above the celestial equator, is respectively maximum and minimum. When the study of the Sun's apparent motion is aimed at gnomonics, it is assumed that the tip of the gnomon coincides with the center of the entire projective system: the stars of lines formed by light rays pass through this point, whose intersection with the surface of the quadrant determines the lines, both hourly and diurnal, responsible for relating each shadow to the corresponding measurement of time.

The restoration of the ancient sundial required the drawing of a celestial sphere 3D model, with the positions of the Sun in the Italic time system [7]. The solstitial circumferences are the symmetrical bases of a cone of light rays having its vertex in the gnomon. The intersections between the cone and the facade determine the diurnal curves of the two solstices on the sundial. This is the gnomonic representation of the cyclic time (Aion), which returns in the succession of the four seasons. It should be noted that the strong declination of the wall has determined a shape for the solstitial hyperbolas significantly different from that one denoted in figure I (the sundial presents $\delta=18.6^{\circ} \mathrm{E}$ ) but, above all, different from the solstitial hyperbolas, with a perfectly vertical transverse axis, which are present in the non-declining sundials $\left(\delta=0^{\circ}\right)$.

On the sphere have also been mapped the time circles in the Italic system and the intersection of each time plane with the surface of the wall determines the corresponding hourly line, a sequence of cairological times which, in the Charterhouse, is from the twelfth to the nineteenth hour [8].

In analogy with what was painted by Carelli, whose dial had not any motto, the diurnal lines were repainted in red, calibrating the thickness (about $2 \mathrm{~cm}$ ) to the size of the traces of

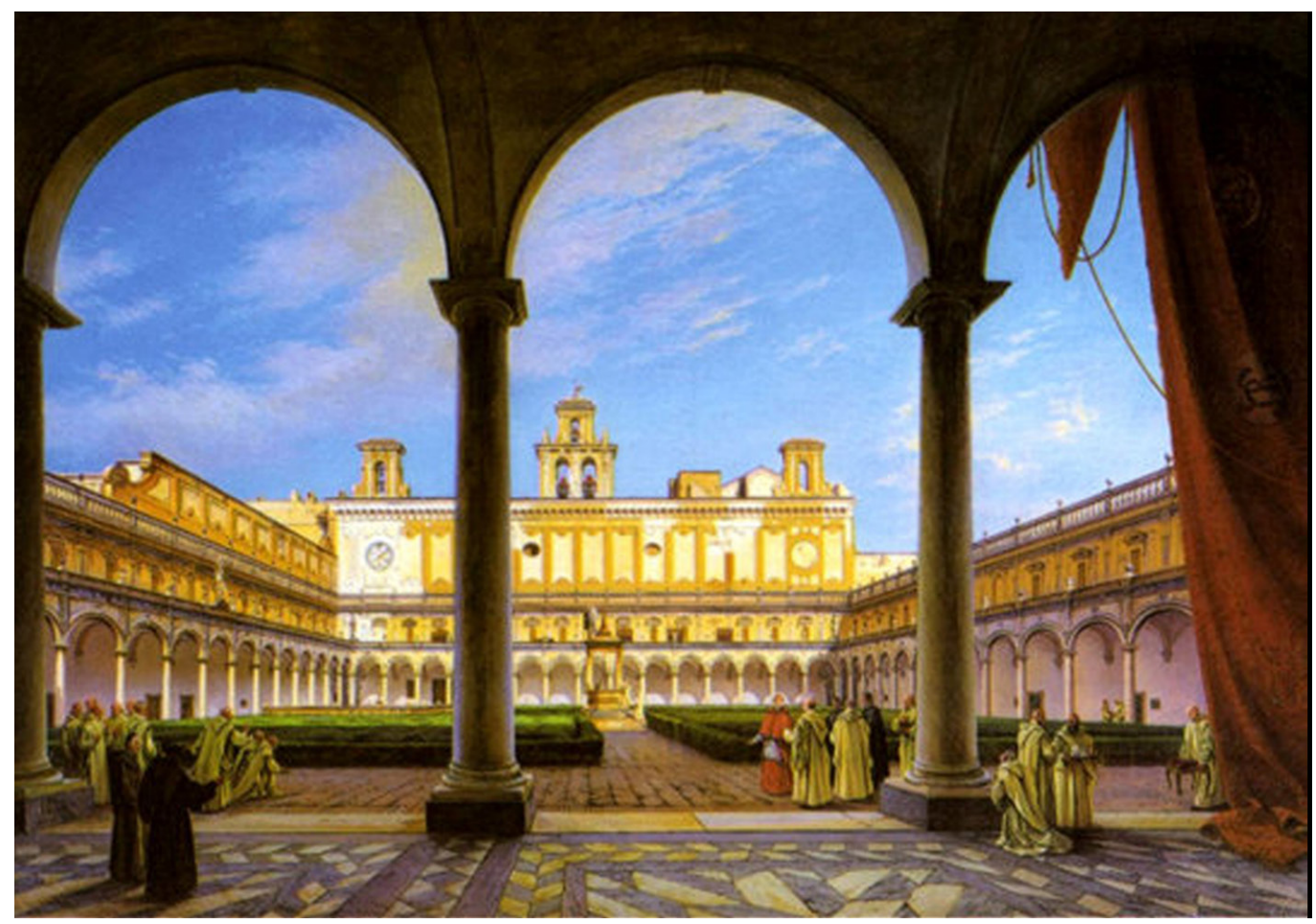


Fig. 6. The celestial sphere for the city of Naples, $\lambda=$ latitude.

Fig. 7. Geometric verification of linear and angular measurements surveyed on the sundial.

Fig. 8. Determination of daily hyperbolas corresponding to the mo solstices, light cones

Fig. 9. Determination of daily hyperbolas corresponding to the two solstices, light cones method, elevation.
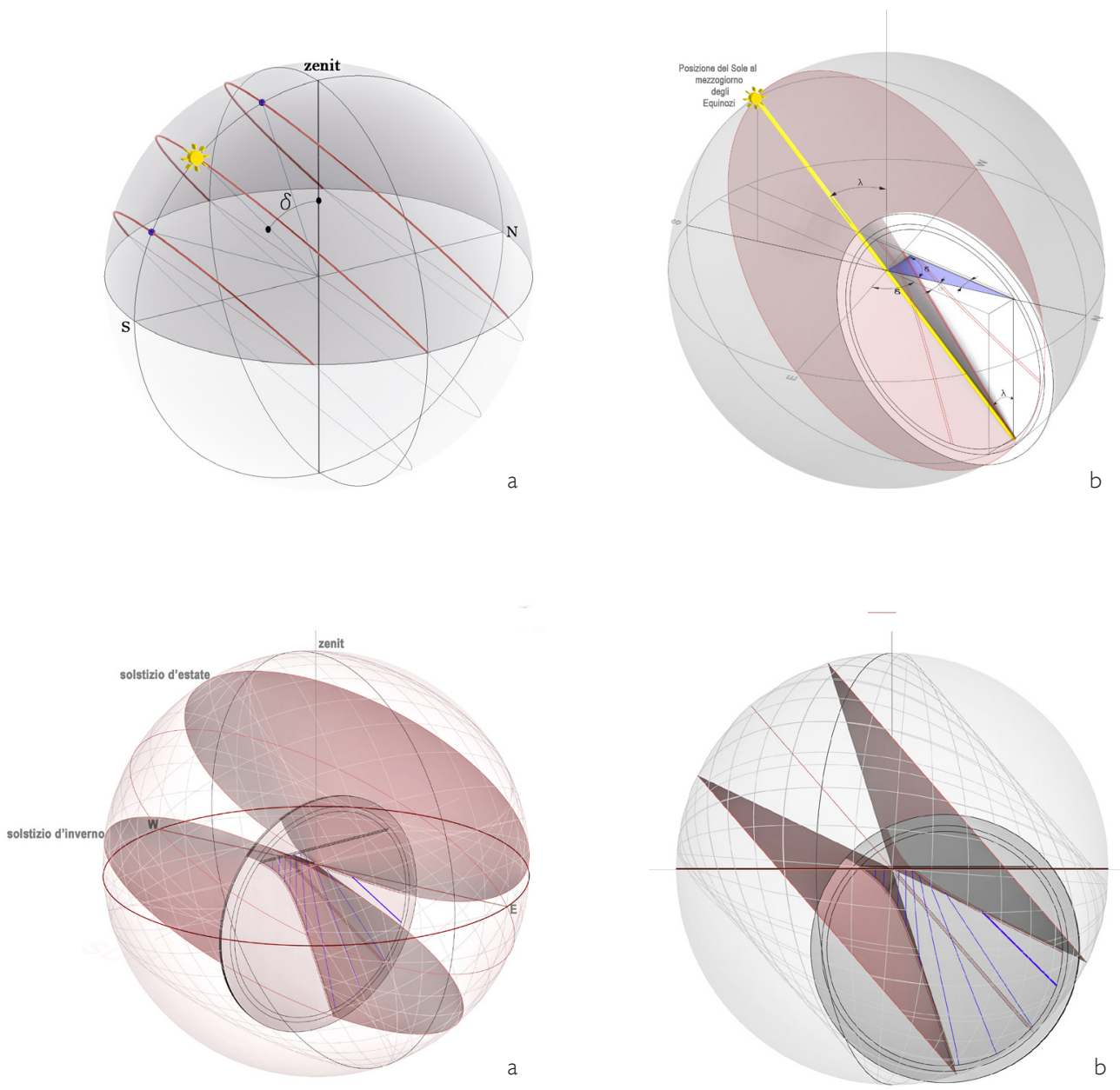

Fig. 10. Determination of the sixteenth hourly straight line as the intersection between the surface of the dial and the corresponding Italic time plan.

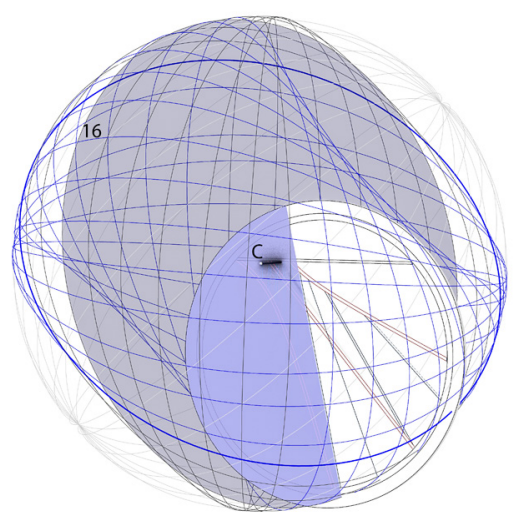


Fig. 1 I. Detail of the restored gnomon and time curves. The restored sundial, 2018

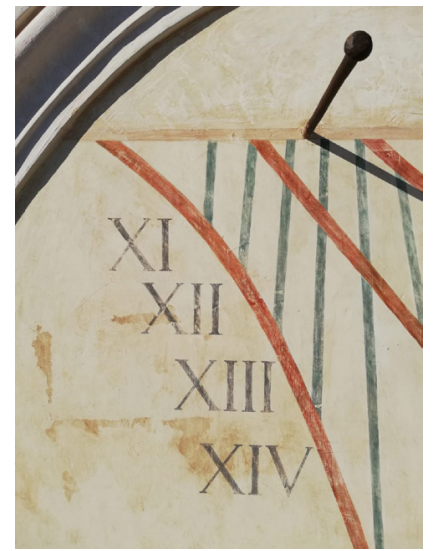

colour surveyed. In order to ensure the optimal readability of the sundial, numerous digital simulations were carried out and it was verified that the line was in any case wider than the shadow projected by the gnomon and that, in the numerous perspective views of an observer located in the Cloister, the typographic character of the numbers to be affixed next to each time line, chosen in analogy with those present in the adjacent mechanical clock, could be clearly visible [9].

\section{Conclusions}

In spite of the scientific and artistic value, many valuable sundials are not adequately preserved and valorized because of the progressive dispersion of this ancient thousand-year-old culture.

The methodological approach of this research aims to reaffirm the importance (and urgency) of bringing the discipline of gnomonics back to the field of drawing and geometry, which originally made measurable on Earth what seemed incommensurable in the sky. Today gnomonics needs to be reread through the disciplines of the origins, after about two centuries of analytical-mathematical specialisms and/or abstractionism that have determined its progressive dispersion. Drawing, geometry and survey should claim their role as necessary and essential tools to interpret and combine the different fields of knowledge that converge in the design and construction of a sundial, with the ultimate goal of valorisation, based on an appropriate action of knowledge and conservation, through conscious restoration.

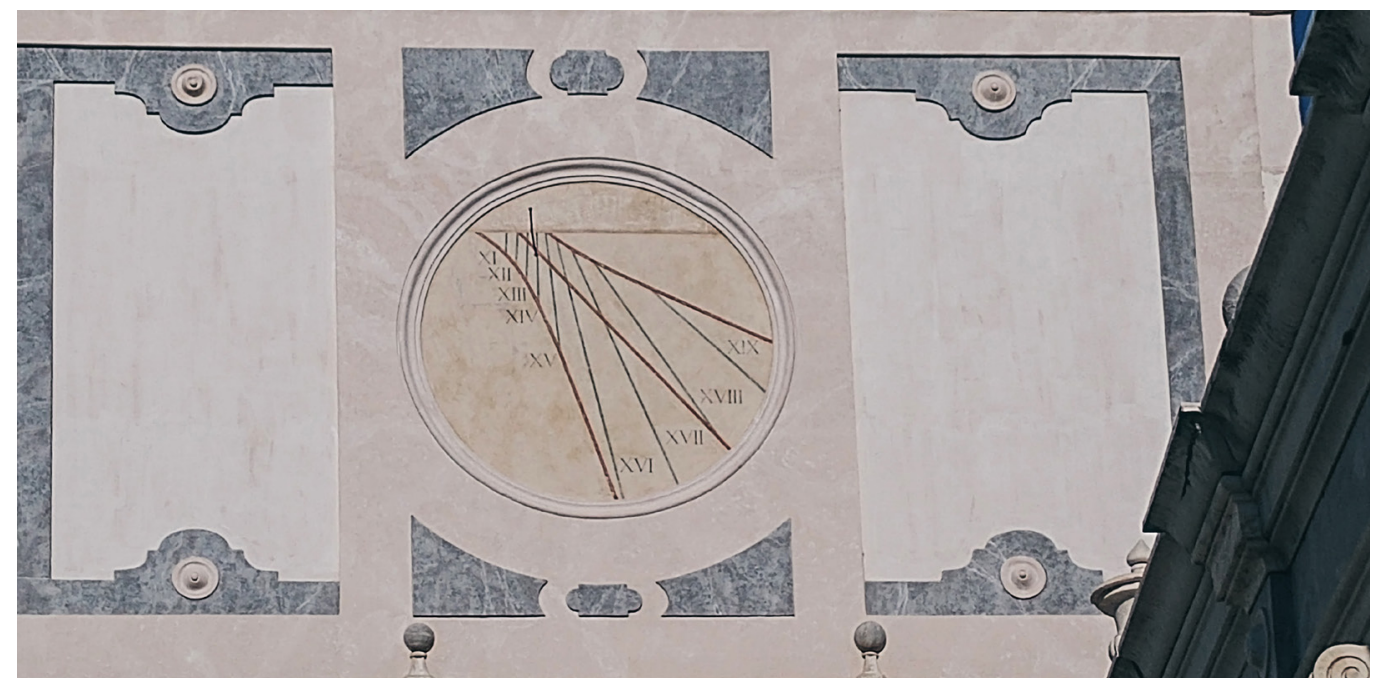




\section{Notes}

[I] The restoration of the four monumental sundials of the astronomer Cassella was recently made by Fondazione Carditello. Project of restoration and recovery of gnomonic functionality: Alessandra Pagliano. Restoration activities: Eugenio Loreto with Struere soc. coop.

[2] (Time) Neither stops nor fail.

[3] These are ancient mechanical clocks that regulated the bell ringing in correspondence with the Italic hours. Equipped with a single hand, these watches had a dial marked only by 6 fractions and therefore the lancet made four complete turns during the day.

[4]The chronometric system ad usum campanae is nothing else but the one with Italic hours moved by half an hour to make the twenty-fourth hour coincide with dusk. The name derives its origin from the function of regulating bells' ringing.

[5] La tecnica SfM, Structure from Motion, basata su algoritmi della ComputerVision, estrae i punti omologhi riconoscibili su due o più foto, rilevandone le coordinate nello spazio.

[6] The gnomonic declination of a vertical wall, not to be confused with the homonymous celestial coordinates of the Sun, is the measure in degrees of the angle formed by the trace of the vertical plane of the facade on the celestial equator, with respect to the cardinal direction E-W, measured counterclockwise.

[7] Diurnal curves on the celestial sphere are common to all chronometric systems.

[8] When the shadow touches, for example, the line of the thirteenth hour, it must be understood that thirteen hours have already passed since the last sunset and therefore eleven hours are missing until the next one, thus highlighting how many hours of light are still available.

[9] The chosen font is $10 \mathrm{~cm}$ high.

\section{References}

Amodeo Federico (1924). Vita matematica napoletana. Parte seconda. Napoli: Accademia Pontaniana.

Ceravolo Tonino (2006). I monaci di clausura. Soveria Mannelli: Rubbettino editore.

D’Anna Nuccio ( 1999). Il gioco cosmico. Tempo ed eternità nell'antica Grecia. Roma: Edizioni mediterranee.

De Lucia Vincenzo ( 183 I). Elementi di Cosmografia e di Cronologia. Napoli: Stamperia de' Fratelli Criscuolo. I

Fittipaldi Teodoro, Casolaro Renato (1995). Il museo di San Martino a Napoli. Napoli: Electa.

Galimberti Umberto (2016). Psiche e techne: l'uomo nell'età della tecnica. Milano: Feltrinelli (9 edizione).

Lalande Jérôme (1769). Voyage d'un françois en Italie, fait dans les annue 1765 et 1766. Venice: Chez Deassaint.

Mandelli Emma, Lavoratti Gaia (a cura di), (20 l0). Disegnare il tempo e l'armonia. II disegno di architettura osservatorio nell'universo. Firenze: Alinea editrice. Firenze.

Pagliano Alessandra, Murolo Roberta, Santoro Luca (2014). Disegnare il tempo. Rocco bovi e gli orologi solari della Certosa di San Martino. Roma: Aracne editrice.

Pagliano Alessandra (20 I 8). Le ore del Sole. Geometria e astronomia negli antichi orologi solari romani. Napoli: Editori Paparo.

Paltrinieri Giovanna (2005). Meridiane e orologi solari d'Italia, con la prefazione di M. Hack. Roma: l'Artiere.

Paradiso Della Monica Giuseppe, Guglielmelli Maria Rosaria (a cura di), (2000). Arenella e dintorni. Napoli: Arte tipografica.

Penta Maria Teresa, Jatta Barbara (2002). Incisioni del '700 in Italia: nella raccolta d'arte Pagliara dell'Istituto Suor Orsola Benincasa. Napoli: Istituto Suor Orsola Benincasa.

Philippson Paula (1949). II concetto greco di tempo nelle parole Aion Chronos Kairos Eniautos. In Storia della filosofia, n. 4, I949, pp. 81-97.

Severino Nicola (2006). L'orologio multiplo della Certosa di San Martino a Napoli: nuove ipotesi e considerazioni. <http://www.nicolaseverino.it>.

Spinosa Nicola (2000). San Martino immagini e memorie. Napoli: Grimaldi \& C. Editori.

Zaccaria Ruggiu Annapaola (2006). Le forme del tempo: Aion, Chronos, Kairos. Padova: Il poligrafo.

\section{Author}

Alessandra Pagliano, Università di Napoli "Federico II", alessandra.pagliano@unina.it

To cite this chapter: Pagliano Alessandra (2020). La gnomonica antica tra arte e scienza: geometria, storia e astronomia per il restauro dell'orologio solare della Certosa di San Martino/The ancient gnomonics between art and science: geometry, history and astronomy for the restoration of the sundial in the Charterhouse of San Martino. In Arena A., Arena M., Brandolino R.G., Colistra D., Ginex G., Mediati D., Nucifora S., Raffa P. (a cura di). Connettere. Un disegno per annodare e tessere. Atti del $42^{\circ}$ Convegno Internazionale dei Docenti delle Discipline della Rappresentazionel Connecting. Drawing for weaving relationships. Proceedings of the 42th International Conference of Representation Disciplines Teachers. Milano: FrancoAngeli, pp. 732-751. 